\title{
The Arabic Origins of "Sex Derivatives and Formally Similar Terms Six, Sack, Sake, Suck, Seek, Soak, Kiss, Case, Cozy" in English and European Languages: A Consonantal Radical Theory Approach
}

\author{
Zaidan Ali Jassem* \\ Department of English Language and Translation, Qassim University, KSA
}

*Corresponding Author: Zaidan Ali Jassem, Department of English Language and Translation, Qassim University, KSA

\begin{abstract}
This paper examines the Arabic origins of sex and its derivatives like sexually, sect, dissection and formally similar but semantically different words like six, sick, sack, sake as well as reversed forms like kiss, case, cozy in English, German, French, Latin, Greek, and Sanskrit from a consonantal radical or lexical root theory perspective. More precisely, the data consists of three different sets of 30 words altogether, 11 of which are sex derivatives like sexual, sexually, sexuality, sect, section, dissection, insect, 13 formally similar but semantically different words like six, sick, sack, sake, suck, seek, beseech, soak, size, and 6 reversed forms like kiss, case, cozy, cuss. The results clearly show that all such related words have true Arabic cognates, with the same or similar forms and meanings whose different forms, however, are all found to be due to natural and plausible causes and different courses of linguistic change. Furthermore, they show the failings of English and European historical lexicography and linguistics in manifesting the close genetic relationships between Arabic and such languages. As a consequence, the results indicate, contrary to Comparative Method and Family-Tree Model claims, that Arabic, English, and all the so-called Indo-European languages belong to the same language, let alone the same family. In fact, they are real dialects of Arabic. Therefore, they prove the adequacy of the consonantal radical theory in relating Indo-European languages to Arabic as their origin all because, unlike any other language in the group, it shares cognates with all of them in addition to its huge linguistic repertoire phonetically, phonologically, morphologically, syntactically, and semantically.
\end{abstract}

Keywords: Sex-Related Words, Arabic, English, German, French, Russian, Latin, Greek, Sanskrit, Lexicography, Historical Linguistics, Consonantal Radical/Lexical Root Theory

\section{INTRODUCTION}

The close genetic relationship between Arabic and the so-called Indo-European languages has been firmly established in 55 papers, covering all aspects of language analysis phonetically, morphologically, grammatically, and lexically or semantically (Jassem 2012-2018). In all those papers, words have been classified into (a) broad semantic fields or areas such as family, water, animal, colour, numeral, religious/divine terms or (b) grammatical functions and categories like pronouns, question words, verb to be, number, gender, case, inflectional and derivational affixes, and the like. The purpose of all these papers is to reject traditional thinking and practice in the field which classifies Arabic and Indo-European languages like English, German, French, Latin, Greek, and Sanskrit as members of different families (Bergs and Brinton 2012; Algeo 2010; Crystal 2010: 302; Campbell 2013; Yule 2006; Crowley 1997: 22-25, 110-111; Pyles and Algeo 1993: 61-94)..

In the present paper, I endeavour to focus more closely on fewer terms or word roots that are similar in form and meaning but have different spellings and pronunciations which are listed in separate entries in English and Indo-European lexicography and linguistics. For example, although sex, sexual, sexuality, sect, section, sectarian, dissection, insect share the same historical meaning 'cut, division', they have separate entries in the dictionary which should, as a matter of fact, be listed under one root as is the practice in Arabic dictionaries (e.g., Albaheth Alarabi 2018; Mu3jam Almaani 2018). In addition, it shows the Arabic origins of formally similar but semantically different terms such as six, sick, sack, seek, beseech, sake, suck, size, seize, and reversed forms like case, cause, cozy, kiss. So this work has three aims: First, it shows the failings of Western linguists and lexicographers 
and their faulty analyses because the descriptions of all European languages were all initially modeled on Latin. Secondly, it tries to link those languages successfully to Arabic which is their end origin all. Finally, it focuses on fewer words which is more beneficial to the reader who does not have either the time or patience to go through long lists of words in a basically glossary-type work. Thus, using fewer related words is easier, faster, and more useful or manageable.

The paper has four sections: introduction, research methods, results, and conclusion. These are taken up one by one next.

\section{RESEARCH METHODS}

\subsection{The Data}

The data consists of three sets of 30 related words: (i) 11 words with the root sec- as in sex, sexual, sexually, sexuality, sexy, sexist, sect, section, sectarian, dissection, insect and (ii) 13 formally similar but semantically different words like six, sick, sack, sake, suck, seek, beseech, size, seize, as well as (iii) 6 reversed words like case, cause, cozy, kiss, cuss. As can be se seen, all the words share the consonants $s-k / k$-s. Their selection has been based on their frequency and related meanings of 'separation, split, division, difference' for the first set despite their different spellings or forms. To facilitate reference, they will be arranged alphabetically but rootwise, together with brief linguistic comments in (3.) below.

The etymological data for English and Indo-European languages is based on Harper (2012-18) and his sources. For Arabic, the meanings are taken from Ibn Manzoor (2018) in the main and related edictionaries like Albaheth Alarabi (2018) and Almaany.com (2018) in addition to my own knowledge of Arabic as a native speaker. Unless otherwise stated, the Arabic cognates of the above English and Indo-European words are exclusively mine, though.

In transcribing the data, normal spelling is used for practical purposes. However, certain symbols were used for unique Arabic sounds, including $/ 2 \tau \& 3 \varepsilon /$ for the voiceless and voiced pharyngeal fricatives respectively, / $\mathrm{kh} \dot{\tau} \&$ gh $\dot{\xi} /$ for the voiceless and voiced velar fricatives each, capital letters

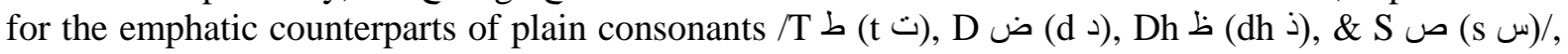
and $/$ ' $\&$ for the glottal stop (Jassem 2013c).

\subsection{Data Analysis}

\subsubsection{Theoretical Framework: Consonantal Radical/Lexical Root Theory}

The analysis of the data utilizes the consonantal radical theory (Jassem 2018c), which is a more precise version of the lexical root (Jassem 2012-2014e) or radical linguistic theory (Jassem 2014f2018b). It is so called because of employing the consonantal radical or, more generally, lexical root in examining genetic relationships between words such as the derivation of observation from serve (or simply srv), description from scribe (or simply scrb), writing from write (or simply wrt). The main reason for that is because the consonantal root carries and determines the basic meaning of the word irrespective of its affixation such as observation. Vowels are thus neglected because they show mainly phonetic and grammatical relationships and functions as in sing (base and present), sang (past), sung (past participle), song (noun).

A full exposition of the lexical root theory and its procedures can be found in Jassem (2018b) which will be skipped over here to save time, effort, and space. However, the main procedures of analysis in relating words to each other genetically can be summed up in five steps as follows.

- Select any word, starting with consonantal roots and overlooking vowels, e.g., the, that, sex, sexual, section.

- Identify the source, daughter, or sister language meaning (e.g., English, Latin) on the basis of especially word history or etymology. It is essential to start with word root meanings, not sounds as the former are more stable and change a lot less than the latter which do so extensively and drastically; for example, all the sounds of a given word might have changeed beyond recognition while meanings in a rather limited way, The meaning first will often lead the analyst to the correct cognate naturally whereas the sounds first will lead them nowhere definitely. 
- Search for the word with the equivalent meaning and form in the target, parent, or reference language (e.g., Arabic), looking for cognates: i.e., sister words with the same or similar forms and meanings.

- Explain the differences, if any, in both form and meaning between the cognates lexicologically, phonetically, morphologically, and semantically as indicated. As a matter of fact, finding the right cognate on the basis of its meaning first often leads one to the resultant changes automatically.

- Finally, formulate phonological, morphological, grammatical, and semantic rules after sufficient data has been amassed and analyzed.

That is the whole story simply and briefly. For example, consider any word in Section 3 below.

\subsubsection{Statistical Analysis}

The percentage formula is used for calculating the ratio of cognate words or shared vocabulary, which is obtained by dividing the number of cognates over the total number of investigated words multiplied by a 100 . For example, suppose the total number of investigated words is 100 , of which 90 are true cognates. The percentage of cognates is calculated thus: $90 / 100=9 \times 100=90 \%$. Finally, the results are checked against Cowley's (1997: 173, 182) formula to determine whether such words belong to the same language or family (for a survey, see Jassem 2012a-b).

\section{RESULTS AND DISCUSSION}

The main focus of the results will be on the Arabic consonantal radicals or lexical roots of English, German, French, Latin, Greek, and Sanskrit words and affixes (prefixes, infixes, and suffixes); vowels will be generally overlooked whose main function is phonetico-grammatical rather than semantic as has been stated earlier.

The first set contains 11 sex-based words, which all mean in general 'separation, split, division', including sexual, sexually, sexuality, sexy, sect, section, sectarian, dissect, dissection, insect. All these words share one common root sec- which means 'separation, split, division, difference' The different forms may be due to 'bad' writing habits of early poorly educated scribes, typists, and printers (Campbell 2013: Chs. 1 \& 2), linguistic variation and change, and/or lexical conditioning. Anyway, all the above words derive from one or two related Arabic main roots or cognates with the same or similar form and meaning, as follows.

Sex originally meant 'cut, division', which came from Latin sexus 'a sex, being male or female', of uncertain origin, from secare (v) 'to divide, cut', seco 'half, division', from PIE root *sek- 'to cut', ultimately from Arabic shaqq 'cut' شق מق, passing /sh \& q/into /s \& k/ and/or splitting /q/ into /ks/.

The Latin masculine suffix - us (Greek -os) of sexus is cognate to Arabic -at 'fem. \& masc. suffix', passing /t/ into /s/. Similarly, the Latin verb marker suffix - are (Greek and Germanic -en) of secare is cognate to Arabic - an 'inflectional and derivational suffix', passing /n/ into /r/.

Sex has several derivatives to which prefixes, infixes, and suffixes may be added, all of which can be traced back to Arabic again very easily and smoothly. These are:

\section{Sexual}

The derivational (adjectival and nominal) suffix - al is cognate to Arabic al- 'the' لـ via morphological shift (Jassem 2016d). So sexual is Arabic al-shaqq-u 'the-section-(nom.)' الثنق to which reordering applied.

\section{Sexually}

The derivational (adverbial, adjectival, and nominal) suffix $-l y$, which developed from Old English lic, lice (adv.) (Modern English like) 'form, shape', is cognate to Arabic shakl, shakli (adj.) 'form, shape 'شكل، شكلي via reversal, /sh \& k/-merger into /k (y)/, and morphological shift (Jassem 2016a). So sexually is Arabic al-shaqq-u shakl 'the-section-(nom.)-shape' شكل النثق(ب) (على).

\section{Sexuality}

The derivational (nominal) suffix -ity is cognate to Arabic -at 'fem. nominal and adjectival suffix' $ت / \mathrm{a}$ via morphological shift (Jassem 2013a). So sexuality is Arabic alshaqq(i)at 'the section' الثقة/الثقية 
Sect stemmed from Old French section, from Latin sectio(nem) 'a cutting, division', from secare (v) 'to divide, cut', from PIE root *sek- 'to cut', from Arabic shaqq(at) (n), shaqqa (v) 'section, cut' شقة ش in which /sh \& q/ became /s \& k/. That is, sect is basically two morphemes sec + -t, the latter of which is the feminine suffix itself in Arabic. Thus, the suffixes $-t$ and -ity are lexically conditioned variants, which may have other linguistically conditioned variants as well like-ette, -ate, -ite, $-s,-i s t$, -ed, $a d$-, de-, etc, which are part of the general $t$-law (Jassem 2017). See sexist below.

Section descended, like sect above, from Old French section, from Latin sectio(nem) 'a cutting, division', from secare (v) 'to divide, cut', directly from Arabic shaqq(atun), shaqqa (v) 'section, cut' شقة، شق where /sh \& q/ became /s \& k/.

The derivational (nominal) suffix -tion is cognate to Arabic -tun 'fem. nominal and adjectival suffix' and its variants -tan and -tin via morphological shift (Jassem 2013a). That is, -tion is originally two bound morphemes which are $-t$ and $-n$, which is exactly the case in Arabic with the former being a feminine suffix whereas the latter a basically (nom. and acc.) case suffix here. In light of this, sect and section are Arabic shaqqat شقة and shaqqatun 'a section (nom.)' شقة respectively.

\section{Sectarian}

The derivational (nominal and adjectival) suffix -arian is cognate to Arabic -an 'masc. nominal and adjectival suffix' ان in which /r/ is an insertion (Jassem 2013a).

\section{Sexist}

The derivational (nominal) suffix -ist is cognate to Arabic -at 'fem./masc. nominal and adjectival suffix' via /t/-split into /st/ and morphological shift (Jassem 2013a). In other words, sexist is Arabic shaqqiat Another likely Arabic cognate is the verbal trilateral prefix ist- استة/شاقية as in katab '(he) wrote' كتب istaktab 'subscribe; to ask someone to write for one' استكتب via morphological shift, though less likely. See sect above.

\section{Sexy}

The derivational (adjectival) suffix $-y$ is an identical cognate to Arabic $-i /-y$ 'adjectival suffix' (Jassem 2013a). So sexy is Arabic shaqqi شقي.

Dissect came from Latin dissecare (v) 'to cut in pieces', from (i) dis- 'apart', and (ii) secare (v) 'to divide, cut', from Arabic shaqqa (v) 'dissect, split' شق where /sh \& q/ became /s \& k/.

The derivational suffix dis- is from Latin which means 'apart', which is incorrect in my view. Instead, it is better treated as a verb-making prefix in this case, which derives from or is cognate to the Arabic derivational and inflectional suffix ta-. Thus, the whole word dissect is from Arabic tashaqqaqat تشققت Jassem 2013a-b).

Dissection stemmed from Middle French dissection, from Latin dissectio(nem), from dissecare (v) 'to cut in pieces' above. So the whole word dissection has three (or four) morphemes dis-, $+\sec (t),+-$ ion, which is what it is exactly in Arabic: ta-shqeeq-(at-un) تشقيقة, from tashaqqaq تثققة, from shaqqa (v) 'dissection, split' شق in which /t, sh, \& q/ became /d, s, \& k/.

Insect has two morphemes or parts in + sect, which are taken direct from Arabic inshaqq(at), from shaqqa (v) 'section, cut' انثقت (منشقة)، شق), passing /sh \& q/ into /s \& k/.

The derivational prefix in- (en-) has several functions and meanings in English and European languages, all of which have true, identical Arabic cognates (Jassem 2012f, 2013a, 2014a). More precisely, it came from Old English in 'in, into, on, upon, at, among, about, during', inne (adv.) 'inside, within', German/Latin in, and Greek en, ultimately from Arabic 3an 'about, on' عن via /3/-loss (see Jassem 2014a). In this particular case, it came, in my view, from Arabic in- 'derivational and inflectional affix' ان , which is more appropriate (see Jassem 2012f, 2013a).

As a negative prefix, furthermore, it, along with $u n$ - and no, can all be considered variants, which ultimately derive straight from Arabic in/an 'no, not' إن/أن (Jassem 2013b).

But what about the formally similar but semantically different on? It came via Old English an/on 'in, on, into', German an, Greek ana, Latin an-, again ultimately from Arabic 3an 'on, about' via /3/loss. That is, Arabic 3an split into or produced two words in English, an obvious case of lexical split. 
Now, we turn to the second set of the 11 rather formally similar but semantically different words six (sestet), seek, beseech, sick, sack, sachet, soak, sock, suck. As can be seen clearly, all such terms have a similar form $s-k$ but different meaning. Again they all have true Arabic cognates with the same or similar form and meaning, which will be illustrated in more detail one by one below.

Six (sixth, sestet) is a numeral which came from German sechs, French sies, Italian sestet, Latin six, and Greek hex, ultimately from Arabic sitt(at) 'six' ست/ستة and related suds 'six; a sixth' سدس, saadis 'sixth' سادس where /d (t)/ passed (or split) into /k(s)/ while /s/ turned into /h/ in Greek (Jassem 2012a, 2014g).

Size is similar in form only which came from Old French sise, short for assise 'session, regulation', from Latin assidere, assidire 'to sit beside; to sit in with counsel or office, from (i) ad 'to and (ii) sidere 'sit', which is incorrect in my view. Instead, it derives directly from Arabic qias, qaas (v) 'size, measure' قياس where /q/ changed into /s/. Thus, the Arabic origin is more relevant, which renders the Latin etymology wrong.

Similarly, seize (seizure) is of uncertain origin, which came from Old French seisir (Modern saisir) 'to take possession, take by force', from Late Latin sacire, perhaps from a Germanic source like Frankish *sakjan 'to lay claim to' (cf. Old English secan 'to seek'), or perhaps from Proto-Germanic *satjan 'to place'. However, it comes directly from Arabic:

- jassa/3assa 'to touch' جس/عس where /j (3) \& s/ evolved into /s \& z/;

- saasa 'to hold/seize power, control' ساس via sense shift and passing/s/ into /z/;

- masak 'to hold, seize' مسك via /m \& s/-merger and turning /k/ into /s/; or

- massa 'to touch' مس where /m/ became /s/.

Sick (sickness, sicken) came from Old English seoc 'ill; corrupt; sad, troubled', straight from Arabic:

- shaki3 'often ill' شكع via /3/-loss and turning /sh/ into /s/;

- $\quad$ shaaki 'ill; complaining' شاكي, turning /sh/ into /s/;

- $\quad$ shawka(t) 'a bad disease' شوكة, changing /sh/ into /s/;

- $\quad$ shaqi 'sad, wretched' شقي via sense shift and passing /sh \& q/ into /s \& k/; or

- Sakeek 'weak' صكيك, turning/S/ into /s/.

The first two are the likeliest.

Sack (sake) has several meanings, which came from Old English sacc/sec 'large cloth bag', from Proto-Germanic *sakkiz (source of Old High German sac), from Latin saccus (French sac, Italian sacco), from Greek sakkos, from Semitic (cf. Hebrew saq 'sack'), directly from Arabic:

- $\quad z a q q$ 'leather bag for drinking water; of birds, to sack, expel, put food into the mouth of its baby; throw; throw up, vomit' زق turning /z \& q/into /s \& k/; or

- Sakk 'to strongly hit, beat, push, esp. with one's feet in animals; shut' صك, substituting /s/ for /S/.

As can be clearly see, the different senses of sack is the result of the lexical merger of two formally similar but semantically different Arabic words.

Seek (sake) evolved from Old English secan 'inquire, search for; long for, desire', from ProtoGermanic *sakanan (source of Old High German sohhan, German suchen), from PIE *sag-yo-, from root *sag- 'to track down, seek out', (source of Latin sagire 'to perceive quickly or keenly', sagus 'predicting, presaging'), straight from Arabic shawq 'longing' شوق, turning /sh \& q/ into /s \& k/; or 3ishq 'love' عشق via semantic shift, /3/-loss, and turning /sh \& q/ into /s \& k/, which is the least likely.

Beseech (seek, sake) is etymologically related to seek above, which came from Old English besecan as a compound of be + seek above. (source of Old High German bisuochan, German besuchen 'to visit'), from Arabic:

- bi + shawq 'with longing' بشوق, turning /sh \& q/ into /s \& ch/; 
- $\quad b i+3 i s h q$ 'with love' بعشق via /3/-loss and turning /sh \& q/ into /s \& ch/; or

- $\quad$ shabaq 'sex desire' شبق via reordering, which is the least likely.

The German meaning 'to visit' also occurs in Arabic. In particular, it is from spoken Damascan Arabic bishuqq 'to cut, visit' بشق, from (i) bi 'verbal prefix' and (ii) shaqqa 'to cut, visit' بشق, turning /sh \& q/ into /s \& ch/ (Jassem 1987).

Sake (seek) developed from Old English sacu 'a law suit, crime, guilt, from Proto-Germanic *sako 'affair, accusation' (source of Dutch zaak 'lawsuit, cause, thing', German Sache 'thing, matter, affair'), from PIE root *sag- 'to investigate, seek out', directly from Arabic shakwa 'complaint' شكوى, shaka (v) شكى, turning /sh/ into /s/.

As to the sense 'Japanese rice liquor', from Japanese sake, it is direct from Arabic siqaa' 'a drink' سقاء, from saqa (v) سقى; /q became /k/.

The expression for the sake of is from Arabic fi (dha) shawq fi 'longing for' في (ذا) شوق (في) =شوقالـ, turning /sh \& q/into /s \& k/ (see Jassem 2014c).

As can be clearly seen, all the senses of sake stem form Arabic as the result of lexical merger where formally similar but semantically different Arabic words merged into or became one in English, though with different senses.

Soak emanated from Old English socian 'to soak, lie in liquid', from Proto-Germanic *sukon (source of West Flemish soken), possibly from PIE *sug-, from root *seue- (2) 'to take liquid', straight from Arabic saqa 'to water, soak' سقى where /q/ became /k/; or Saqa3 'to become cold or ice; to throw cold water on someone' صقع via sense shift and turning /S, q, \& 3/ into /s, k, \& Ø/.

Sock (socks, socket) came from Old English socc 'slipper, light shoe', Old High German soc, German Socke, from Latin soccus 'slipper, light low-heeled shoe', probably from Greek sykchos 'a kind of shoe', from Arabic:

- shikk 'a cloth worn over shoes' شك via lexical shift and turning /sh/ into /s/;

- ziqq 'a leather bag' زق via lexical shift and turning /z \& q/into /s \& k/;

- $\quad$ shis3 'upper, front part of shoe' turning /sh, s \& 3/ into /s, k, \& Ø/; or

- shaqa3 'to wear one's shoes' شقع via lexical shift and turning /sh, q, \& 3/ into /s, k, \& Ø/.

The first two are the likeliest.

Cyst (cystitis) came from Latin cystis, from Greek kystis 'bladder, pouch', from Arabic kees(at) 'bag, sachet, sac' كيس; /k/ passed into /s/.

Finally, we come to the last list of 6 reversed forms, which are kiss, case, cause, cozsy (cosy), cuss (curse), all of which share the reversed form of $s--k$ : i.e., $k-s$. Again all have Arabic cognates as follows.

Kiss developed from Old English coss (n) 'a kiss, embrace', from cyssan (v) 'to touch with the lips', from Proto-Germanic *kussjan (source of Dutch, Old High German kussen, German küssen), from root *kuss-, probably ultimately imitative of the sound, ultimately from Arabic:

- kais 'making love, sexual intercourse; mind; bag' كيس and related koosa/koosia 'woman' via lexical shift;

- $\quad k a(a) f a 2, k i f a a 2$ (n) 'kiss suddenly', merging /f \& 2/ into /s/;

- $k a s s$ 'of teeth, short; lower teeth being fronter than upper ones' via lexical shift; or

- $k a z z a$ 'to press/push (teeth)' via lexical shift and changing /z/ to /s/ (Jasem 2013o).

The French expression donne moi un bousse 'give me a kiss' is entirely Arabic- i.e., addeeni bosa 'give me a kiss' أديني بوسة (لأجل النبي.).

Case (encase, encasement, pillowcase, bookcase) has several senses and etymologies, which came from Old French cas 'event, happening, quarrel, trial', from Latin casus 'a chance, occasion, accident; 
lit., a falling', from cas-, past participle stem of cadere (v) 'to fall, sink, decline, perish', from PIE root *kad- 'to fall', directly from Arabic:

- $\quad k a t t a$ 'of water, to spill, pour down; of earth, to go downhill; slope; to throw' كت/كتة, replacing $/ \mathrm{t} /$ by $/ \mathrm{d}(\mathrm{s}) /$;

- ghaaT (ghaTT) 'to lie low, go down; immerse, dip' غاط، غط, passing /gh \& T/ into /k \& d (s)/;

- $\quad$ خhassa 'to become little' passing /kh/into /k/; or

- ghaaS 'sink, go down' غاص/غص where /gh \& S/ became /k \& s/.

It may also derive from Old French casse (Modern chasse) 'case, reliquary, receptacle, box, that which encloses or contains; outer protective covering', from Latin capsa 'box, repository', from capere 'to take, hold', from PIE root *kap- 'to grasp', which, although it is inaccurate in my view, comes straight from Arabic qafaS 'a nest; box; chest' ققص, replacing /q/ by /k/ and merging /f \& S/ into /k/. However, it comes directly from Arabic:

- kees 'bag, sachet, sac' كيس, which is the likeliest;

- $\quad k a s a$ 'to clothe; to encase' كسا.

- $q i S S a(t)$ 'story, issue, situation, event' ' قصة, from qaSSa (v) 'reduce, cut; follow; tell; chest' قص , turning /q \& S/ into /k \& s/; or

- qaDia(t) 'story, issue, case' قضية, from qaDa (v) 'die; judge, execute' قضىى, passing /q \& D/ into $/ \mathrm{k} \& \mathrm{~s} /$.

All these formally similar but semantically different Arabic words merged into one in English and European languages.

Cause (causative, causation, causal, because; accuse, accusation) came from Old French cause 'reason, case in law', from Latin causa 'reason, interest, lawsuit', of unknown origin; however, it comes from Arabic:

- qiSSa(t) 'cause, reason; story, issue' قصة qaSSa (v) 'to tell; follow, pursue' قص /q \& S/ changed into $/ \mathrm{k} \& \mathrm{~s} /$

- qaDia(t) 'case, story, issue' قضية, qaDa (v) 'to judge' قضى where /q \& D/ became /k \& s/; or

- khuSooS, khaSS 'interest; link; belonging; reason' خصوص، خص where /kh \& s/ becme /k \& s/; or

- shakwa 'complaint; lawsuit' شكوى, shaka (v) via reversal and turning /sh/ into /s/ (see sake above).

All its derivational suffixes have already been settled.

Cozy (cosy) is from Scottish English colsie 'comfortable, warm, snug; padded covering for a teapot to keep the heat in', perhaps of Scandinavian origin; however, it came straight, like case above, from Arabic kees (kuwais (dim.)) 'bag, sachet, sac' كبس، كويس/كويس and/or kaiyes/kuwaies 'nice'. كيس. It is an ideal case of lexical merger: i.e., two formally similar but semantically different Arabic words became one in English with two senses

Cuss (curse) is from American English meaning 'troublesome person or animal; to say bad words', a vulgar pronunciation of curse 'to swear at, to say bad words', from Arabic khasees 'lowly person, cheap' خسيس and/or khasi'a, ikhs (imp.) 'of insults, to be lowly; to swear at, insult' خسئ، اخس where /kh/ became $/ \mathrm{k} /$.

As to curse, it is direct from Arabic kharas, ikhras (imp.) 'shut up'خرس، اخرس where /kh/ passed into /k/.

Concise (incise, incision, precise) derives from Latin concisus 'cut off, brief', past participle of concidere 'to cut off, cut up, cut to pieces', from (i) com-/co- 'an intensive prefix' and (ii) caedere 'to cut', from PIE root *kae-id- 'to strike', straight from Arabic qaTa3/qaTTa/qadda 'to cut' قطع/قط/:قد, turning /q, T (d), \& 3/ into /k, d, \& Ø/. However, such an etymology is inaccurate in my view; instead, it comes straight from Arabic: 
The Arabic Origins of "Sex Derivatives and Formally Similar Terms Six, Sack, Sake, Suck, Seek, Soak, Kiss, Case, Cozy" in English and European Languages: A Consonantal Radical Theory Approach

- jazza 'of wool, to cut' ج, passing /j \& z/ into /k \& s/; or

- qaSSa 'to cut' قص in which /q \& S/ became /k (s) \& s/.

(See size, seize above)

To sum up, the total number of words with the roots $s-k$ and its reversed form $k$-s thus far has amounted to 30 or so, all of which have true Arabic cognates, which implies that all those languages from English and German to Latin and Greek relate to Arabic genetically; in fact, they are old, deviant Arabic dialects .

\section{CONCLUSION}

To conclude, the main findings of this paper were as follows:

- All the 11 sex-related words share, despite their apparently different spellings or forms, the same or similar meaning of 'division, split, separation, difference, opposition', which consequently derive from one true and identical ultimate Arabic cognate or root shaq شق whose resultant differences stemmed from natural and plausible causes and different routes of language change in each language. The same applies to the 11 formally similar but semantically different words like six, sick, sack, sake, suck, soak, sock, seek, size, and 7 reversed forms case, cause, kiss, cozy, cuss (curse), concise.

- The findings lend further support to the adequacy of the consonantal radical theory, the more precise version of the lexical root or radical linguistic theory, in relating English and IndoEuropean words, roots, and affixes to Arabic from which they eventually arose for sharing cognates with them all.

- English Historical lexicography and linguistics abound with severe etymological aberrances, drawbacks, and implausibilities for failing to show the phonetic, morphological, grammatical, and semantic relationships amongst such words like sex, section, dissection and six, sick, sack, sake, suck, soak, seek in addition to case, cause, kiss, cozy, cuss as well as their Arabic origins.

$>$ Not all English and European words are cognates such as English size and French/Latin assidere and English soak and PIE root *seue-, which are actually different words that can be traced back to Arabic cognates more appropriately.

$>$ Postulating Proto-Indo-European and Proto-Germanic roots as well as uncertain or unknown ones turns out to be a myth since Arabic can provide really living and true cognates for all words in those languages as has been clearly shown above.

$>$ Semantic change may result from lexical merger and split. On the one hand, the multiple meanings of English words such as sake and case and cosy (see above) are most likely the result of the lexical merger of two or more Arabic cognates which are similar in both form and meaning: i.e., shakwa 'case, complaint' and qiSSa 'issue' (see above); also, sake merges Arabic shawq and shakwa. On the other hand, lexical split is the result of an Arabic word yielding formally similar but semantically different words like English sex, section, dissect, etc. from Arabic shaqq, Englsih sake, seek, beseech from Arabic shawq, and English case/cosy/cyst from Arabic kees/kais.

\section{REFERENCES}

[1] Albaheth AlArabi: Qamoos Arabi. (2018). Retrieved http://www.baheth.info (October 10, 2018).

[2] Almaany.com. (2018). Retrieved http://www.almaany.com (October 10, 2018).

[3] Bergs, Alexander and Brinton, Laurel (eds). (2012). Handbook of English historical linguistics. Berlin: Walter de Gruyter.

[4] Campbell, L. (2013). Historical linguistics: An introduction. (3 ${ }^{\text {rd }}$ edn). Edinburgh: Edinburgh University Press.

[5] Crowley, T. (1997). An Introduction to historical linguistics. (3rd edn). Oxford: Oxford University Press.

[6] Harper, Douglas. (2001-2018). Online etymology dictionary. Retrieved http://www.etymonline.com (October 10, 2018).

[7] Ibn Manzoor, Abi Alfadl Almisri. (2018). Lisan al3arab. Beirut: Dar Sadir. Retrieved http://www.baheth .info (October 10, 2018). 
The Arabic Origins of "Sex Derivatives and Formally Similar Terms Six, Sack, Sake, Suck, Seek, Soak, Kiss, Case, Cozy" in English and European Languages: A Consonantal Radical Theory Approach

[8] Jassem, Zaidan Ali. (1987). Phonological variation and change in immigrant speech: A sociolinguistic study of a 1967 Arab-Israeli war immigrant speech community in Damascus, Syria. PhD Thesis, Durham University, UK. Retrieved http://etheses.dur.ac.uk/1682/1/1682.pdf (October 10, 2018).

[9] Jassem, Zaidan Ali. (2012a). The Arabic origins of numeral words in English and European languages. International Journal of Linguistics 4 (3), 225-41. Retrieved URL: http://dx.doi.org/10.5296/ijl.v4i3.1276 (October 10, 2018).

[10] Jassem, Zaidan Ali. (2012b). The Arabic origins of common religious terms in English: A lexical root theory approach. International Journal of Applied Linguistics and English Literature 1 (6), 59-71. Retrieved URL: http://dx.doi.org/10.7575/ijalel.v.1n.6p.59 (October 10, 2018).

[11] Jassem, Zaidan Ali. (2012c). The Arabic origins of English pronouns: A lexical root theory approach. International Journal of Linguistics 4 (4), 83-103. Retrieved URL: http://dx.doi.org/10.5296/ijl.v4i4.227 (October 10, 2018).

[12] Jassem, Zaidan Ali. (2012d). The Arabic origins of determiners in English and European languages: A lexical root theory approach. Language in India 12 (11), 323-359. Retrieved URL: http://www.languageinindia.com (October 10, 2018).

[13] Jassem, Zaidan Ali. (2012e). The Arabic Origins of Verb "To Be" in English, German, and French: A Lexical Root Theory Approach. International Journal of Applied Linguistics and English Literature 1 (7), 185-196. Retrieved URL: http://dx.doi.org/10.7575/ijalel.v.1n.7p.185 (October 10, 2018).

[14] Jassem, Zaidan Ali. (2012f). The Arabic origins of number and gender markers in English, German, French, and Latin: a lexical root theory approach. Language in India 12 (12), 89-119. Retrieved URL: http://www.languageinindia.com (October 10, 2018).

[15] Jassem, Zaidan Ali. (2013a). The Arabic origins of derivational morphemes in English, German, and French: A lexical root theory approach. Language in India 13 (1), 48-72. Retrieved URL: http://www. languageinindia.com (October 10, 2018).

[16] Jassem, Zaidan Ali. (2013b). The Arabic origins of negative particles in English, German, and French: A lexical root theory approach. Language in India 13 (1), 234-48. Retrieved URL: http://www.language inindia.com (October 10, 2018).

[17] Jassem, Zaidan Ali. (2013c). The English, German, and French cognates of Arabic back consonants: A lexical root theory approach. International Journal of English and Education 2 (2): 108-128. Retrieved URL: http://www.ijee.org (October 10, 2018).

[18] Jassem, Zaidan Ali. (2013d). The Arabic origins of "water and sea" terms in English, German, and French: A lexical root theory approach. Language in India 13 (2): 126-151. Retrieved URL: http://www.language inindia.com (October 10, 2018).

[19] Jassem, Zaidan Ali. (2013e). The Arabic origins of "air and fire" terms in English, German, and French: A lexical root theory approach. Language in India 13 (3): 631-651. Retrieved URL: http://www.language inindia.com (October 10, 2018).

[20] Jassem, Zaidan Ali. (2013f). The Arabic origins of "celestial and terrestrial" terms in English, German, and French: A lexical root theory approach. International Journal of English and Education 2 (2): 323-345. Retrieved URL: http://www.ijee.org (October 10, 2018).

[21] Jassem, Zaidan Ali. (2013g). The Arabic origins of "animal" terms in English and European languages: A lexical root theory approach. Language in India 13 (4): 68-106. Retrieved URL: http://www.language inindia.com (October 10, 2018).

[22] Jassem, Zaidan Ali. (2013h). The Arabic origins of "body part" terms in English and European languages: A lexical root theory approach. International Journal of Current Applied Linguistics and English Literature (1). Retrieved URL: http://www.bretj.com (October 10, 2018).

[23] Jassem, Zaidan Ali. (2013i). The Arabic origins of "speech and writing" terms in English and European languages: A lexical root theory approach. Language in India 13 (5): 108-159. Retrieved URL: http://www languageinindia.com (October 10, 2018).

[24] Jassem, Zaidan Ali. (2013j). The Arabic origins of "time words" in English and European languages: A lexical root theory approach. Language in India 13 (6): 274-97. Retrieved URL: http://www.language inindia.com (October 10, 2018).

[25] Jassem, Zaidan Ali. (2013k). The Arabic origins of "family words" in English and European languages: A lexical root theory approach. International Journal of English and Education 2 (3): 261-77. Retrieved URL: http://www.ijee.org (October 10, 2018).

[26] Jassem, Zaidan Ali. (20131). al'uSool al3arabiat lilDamaa'ir alshakSiat fi alingleeziat, walfiransiat, walalmaniat (The Arabic origins of "personal pronouns" in English, German, and French: A lexical root theory approach (In Arabic). Almu'tamar aldawli althamin, tajdeed alkhiTaab al3arabi, jaami3at imam 
The Arabic Origins of "Sex Derivatives and Formally Similar Terms Six, Sack, Sake, Suck, Seek, Soak, Kiss, Case, Cozy" in English and European Languages: A Consonantal Radical Theory Approach

bonjul, Indonesia 28-31 August 2013 (8 $8^{\text {th }}$ International Conference of Arabic Speech Renewal, Imam Bonjul University, Indonesia, 28-31 August 2013). Retrieved URL: http://www.academia.edu (October 10, 2018).

[27] Jassem, Zaidan Ali. (2013m). The Arabic origins of "cutting and breaking words" in English and European languages: A lexical root theory approach. Research Journal of English Language and Literature 1 (2): 155-68. Retrieved URL: http://rjelal.com (October 10, 2018).

[28] Jassem, Zaidan Ali. (2013n). The Arabic origins of "movement and action words" in English and European languages: A lexical root theory approach. Research Journal of English Language and Literature 1 (3): 187-202. Retrieved URL: http://rjelal.com (October 10, 2018).

[29] Jassem, Zaidan Ali. (2013o). The Arabic origins of "perceptual and sensual words" in English and European languages: A lexical root theory approach. Research Journal of English Language and Literature 1 (4): 212-24. Retrieved URL: http://rjelal.com (October 1. 2018).

[30] Jassem, Zaidan Ali. (2013p). The Arabic origins of "cognitive and mental words" in English and European languages: A lexical root theory approach. International Journal of English and Education 2 (4): 65-83. Retrieved URL: http://www.ijee.org (October 10, 2018).

[31] Jassem, Zaidan Ali. (2013q). The Arabic origins of "love and sexual words" in English and European languages: A lexical root theory approach. International Journal of Language and Linguistics 1 (4): 97114. Retrieved URL: http://www.ijll.org (October 1. 2018).

[32] Jassem, Zaidan Ali. (2014a). The Arabic origins of "wining and dining words" in English and European languages: A lexical root theory approach. International Journal of English and Education 1 (4): 146-74. Retrieved URL: http://www.ijee.org (October 10, 2018).

[33] Jassem, Zaidan Ali. (2014b). The Arabic origins of "question and auxiliary words" in English and European languages: A lexical root theory approach. International Journal of Language and Linguistics 2 (1). Retrieved URL: http://www.ijll.org (October 10, 2018).

[34] Jassem, Zaidan Ali. (2014c). The Arabic origins of "prepositions and conjunctions" in English and European languages: A lexical root theory approach. Journal for the Study of English Linguistics 2 (1). Retrieved URL: http://www.jsel.org (October 10, 2018).

[35] Jassem, Zaidan Ali. (2014d). Translating cultural universals radically: A lexical root theory approach for translating English, French, and German cultural terms into Arabic. Paper presented at International Conference on Translation and the Problematics of Cross-Cultural Understanding, the Forum for Arab and International Relations, Doha, Qatar 26-27 February 2014.

[36] Jassem, Zaidan Ali. (2014e). The Arabic origins of "divine and theological terms" in English, German, and French: A lexical root theory approach. Language in India 14 (3): 155-195. Retrieved URL: http://www.languageinindia.com (October 10, 2018).

[37] Jassem, Zaidan Ali. (2014f). The Arabic origins of "proper names" in English and European languages: A lexical root theory approach. Research Journal of ELT and Poetry 2 (2): 201-22. Retrieved URL: http://www.journalofelt.in (October 10, 2018).

[38] Jassem, Zaidan Ali. (2014g). The Arabic origins of "mathematical and computational terms" in English and European languages: A lexical root theory approach. International Journal on Studies in English and Literature 2 (5): 21-40. Retrieved URL: http://www.arcjournals.org/ijsell (October 10, 2018).

[39] Jassem, Zaidan Ali. (2014h). The Arabic origins of "Mandarin Chinese Pronouns": A radical linguistic theory approach. International Journal of English and Education 3 (3). Retrieved URL: http://www.ijee.org (October 10, 2018).

[40] Jassem, Zaidan Ali. (2014i). The Arabic origins of "Finnish and Basque Pronouns": A radical linguistic theory approach. Journal of English language and literature 2 (1): 109-20. Retrieved URL: http://www.jellonline.com (October 10, 2018).

[41] Jassem, Zaidan Ali. (2014j). The Arabic origins of English and Indo-European "colour and artistic terms": A radical linguistic theory approach. International Journal of English language, literature, and Translation 1 (1): 1-14. Retrieved URL: http://www.ijels.com (October 10, 2018).

[42] Jassem, Zaidan Ali. (2014k). I buy, Ich kaufe, \& J'achéte as Arabic Dialectal Variants: A radical linguistic theory approach. International Journal of language and linguistics 2 (5): 317-27. Retrieved URL: http://www.sciencepublishinggroup.com/ijll. Doi: 10.11648/j.ijll.20140205.15 (October 10, 2018).

[43] Jassem, Zaidan Ali. (20141). Radical translation and translating names: A lexical root theory approach. Paper to be presented at ASELS International Conference 2014, Abdel Malek Essadi University, Tangier, Morocco, 25-27 November 2014.

[44] Jassem, Zaidan Ali. (2015a). The Arabic origins of English and Indo-European "life and death terms": A radical linguistic theory approach. International Journal of English and Education 4/1: 322-345. Retrieved URL: http://www.ijee.org (October 10, 2018). 
The Arabic Origins of "Sex Derivatives and Formally Similar Terms Six, Sack, Sake, Suck, Seek, Soak, Kiss, Case, Cozy" in English and European Languages: A Consonantal Radical Theory Approach

[45] Jassem, Zaidan Ali. (2015b). Towards a radical translation theory for names: A comparative historical linguistics approach. International Journal of English and Education 4/1: 298-321. Retrieved URL: http://www.ijee.org (October 10, 2018).

[46] Jassem, Zaidan Ali. (2015c). The Arabic origins of English and Indo-European "medical terms": A radical linguistic theory approach. Journal of English Language and Literature 2/1: 18-47. Retrieved URL: http://www.joell.in (October 10, 2018).

[47] Jassem, Zaidan Ali. (2015d). The Arabic origins or cognates of English and Indo-European "case markings and word order": A radical linguistic theory approach. Language in India 15/3: 104-40. Retrieved URL: http://www.languageinindia.com (October 1, 2018).

[48] Jassem, Zaidan Ali. (2015e). The Arabic origins of English and Indo-European "democratic terms": A radical linguistic theory approach. Journal of English Language and Literature 2/2: 111-139. Retrieved URL: http://www.joell.in (October 10, 2018).

[49] Jassem, Zaidan Ali. (2015f). The Arabic origins of English and Indo-European "military terms": A radical linguistic theory approach. Language in India 15/5: 105-139. Retrieved URL: http://www.languageinindia. com (October 10, 2018).

[50] Jassem, Zaidan Ali. (2015g). The Arabic origins of English and Indo-European "legal terms": A radical linguistic theory approach. Journal of Applied Linguistics and Translation 1/3. Retrieved URL: http://www.languageinindia.com (October 10, 2018).

[51] Jassem, Zaidan Ali. (2015i). The Arabic origins of English and Indo-European "urban terms": A radical linguistic theory approach. English Review: Journal of English Education 3/2: 146-166. Retrieved URL: http://www.journal.uniku.ac.ind/index.php/ERJEE (October 10, 2018)

[52] Jassem, Zaidan Ali. (2015j). Negation in world languages: A radical linguistic theory approach. Veda's Journal of English Language and Literature 2/4: 1-17. Retrieved URL: http://www.joell.in (October 10, 2018)

[53] Jassem, Zaidan Ali. (2016a). The Arabic origins of "plural markers" in world languages: A radical linguistic theory approach. International Journal of English and Education 5/1: 193-223. Retrieved URL: http://www.ijee.org (October 10, 2018). (Also in Indonesian EFL Journal 1 (2): 144-163, 2015.)

[54] Jassem, Zaidan Ali. (2016b). The Arabic origins of English and Indo-European "floral terms": A radical linguistic theory approach. International Journal on Studies in English and Literature 4 (2): 81-99. Retrieved URL: http://www.arcjournals.org/ijsell (October 10, 2018).

[55] Jassem, Zaidan Ali. (2016c). The Arabic origins of English and Indo-European "fashion and modeling terms": A radical linguistic theory approach. International Journal on Studies in English and Literature 4 (6): 40-60. Retrieved URL: http://dx.doi.org/10.20431/2347-3134.0405007 (October 10, 2018).

[56] Jassem, Zaidan Ali. (2016d). The Arabic origins of English and Indo-European "definite articles": A radical linguistic theory approach. International Journal of English Language, Literature and Humanities 4/6: 530-55. Retrieved URL: http://www.ijellh.com/wp-content/uploads/2016/06/64.-Zaidan-Ali-Jassempaper-final.pdf?cec.7d6 (October 10, 2018)

[57] Jassem, Zaidan Ali. (2016e). English, German, French, Latin, Greek, and Sanskrit are entirely Arabic- Free Good Lovely Comely Merry Beautiful Girls Marry Noble Villains in Wedding and Engagement Rings Ceremoniously: A radical linguistic theory approach. International Journal of English and Education 5/3: 33556. Retrieved URL: http://www.ijee.org/yahoo_site_admin/assets/docs/26.19215751 .pdf (October 10, 2018)

[58] Jassem, Zaidan Ali. (2016f). The Arabic origins and development of English, German, and French: A radical linguistic theory approach. Proceedings of $9^{\text {th }}$ International Conference on Allugha Alarabia asas althaqafa alinsania 'Arabic as the Basis of Human Culture' Vol. 1. University of Jakarta in Cooperation with The University of Science and Technology of Jordan, and Indonesia's Arabic Teachers' Association, Jakarta, Indonesia, 9-10 August 2016, pp. 363-404.

[59] Jassem, Zaidan Ali. (2016g). Vocabulary learning and teaching: A radical linguistic theory approach. Proceedings of $10^{\text {th }}$ International Conference on Arabic Language and Culture in Inter-Continental Educational Institutions (PINBA X IMLA), Vol. 1. The State Institute of Islamic Studies Pontianak in Cooperation with Arabic Teachers' Association of Indonesia, West Kalimantan, Indonesia, 26-28 August 2016, pp. 50-70.

[60] Jassem, Zaidan Ali. (2016h). Campbell's (2013) Historical linguistics: An introduction: A critical review. International Journal of English Language, Literature and Humanities 10/6: 530-55. Retrieved URL: http://www.ijellh.com/wp-content/uploads/2016/06/64.-Zaidan-Ali-Jassem-paper-final.pdf?cec.7d6 (October 10, 2018)

[61] Jassem, Zaidan Ali. (2016i). Medical Translation: A Radical Linguistic Theory Approach. In الترجمة و إثكالات المثاقفة Understanding), the Forum for Arab and International Relations, Doha, Qatar 12-13 December 2016. 
The Arabic Origins of "Sex Derivatives and Formally Similar Terms Six, Sack, Sake, Suck, Seek, Soak, Kiss, Case, Cozy" in English and European Languages: A Consonantal Radical Theory Approach

[62] Jassem, Zaidan Ali. (2017a). Harper's Etymology Dictionary Online (etymonline): A critical review. International Journal of English and Education 6/1: 335-56. Retrieved URL: http://www.ijee.org/yahoo_site_admin/assets/docs/26.19215751.pdf (October 10, 2017)

[63] Jassem, Zaidan Ali. (2017b). Myth and Fallacy in the Oxford English Dictionary: A Critique with Reference to "That Girl Marries the Villain". Veda's Journal of English Language and Literature 4/1: 4255. Retrieved URL: http://www.joell.in (October 10, 2018)

[64] Jassem, Zaidan Ali. (2018a). The Arabic origins or cognates of negative terms in world languages: A radical linguistic theory approach. International Journal of English and Education 7/1: 124-52. Retrieved URL: http://www.ijee.org/yahoo_site_admin/assets/docs/10.5125350.pdf (October 10, 2018)

[65] Jassem, Zaidan Ali. (2018b). The Arabic origins or cognates of names of "Week Days" in English and European Languages: A lexical root theory approach. International Journal of English and Education 7/2: 273-94. Retrieved URL: http://www.ijee.org/yahoo_site_admin/assets/docs/10.5125350.pdf (October 10, 2018)

[66] Jassem, Zaidan Ali. (2018c). The Arabic origins or cognates of English and European place names: A consonantal radical theory approach. Indian Journal of Arts 8: 90-102. Retrieved URL: http://www.discoveryjournals.org/arts/current_issue/2018/A11.pdf (October 10, 2018)

[67] Pyles, T. and J. Algeo. (1993). The origins and development of the English language. (4th edn). San Diego: HBJ.

\section{AUTHOR'S BIOGRAPHY}

Zaidan Ali Jassem holds a PhD in Linguistics from Durham University, UK, in 1987. Since then, he has been teaching linguistics and ELT in Syrian, Malaysian, and Saudi universities. Currently, he is professor of English Language and Linguistics at Qassim University, KSA. His research interests include the full spectrum of language sciences, especially sociolinguistics, historical linguistics, ELT, and translation. His current interest focuses on the Arabic origins of English and Indo-European languages which has attracted my attention since the first day I set my footsteps in the English countryside.

Citation: Zaidan Ali Jassem. "The Arabic Origins of "Sex Derivatives and Formally Similar Terms Six, Sack, Sake, Suck, Seek, Soak, Kiss, Case, Cozy" in English and European Languages: A Consonantal Radical Theory Approach". International Journal on Studies in English Language and Literature (IJSELL), vol 6, no.10, October2018, pp. 41-52. doi:http://dx.doi.org/10.20431/2347-3134.0610005.

Copyright: (C) 2018 Authors. This is an open-access article distributed under the terms of the Creative Commons Attribution License, which permits unrestricted use, distribution, and reproduction in any medium, provided the original author and source are credited. 